Received 28.04.2017 Reviewed 06.06 .2017 Accepted 13.09.2017

A - study design

B - data collection

C - statistical analysis

D - data interpretation

E - manuscript preparation

F - literature search

\section{Carbon dioxide emission from raised bog surface after peat extraction}

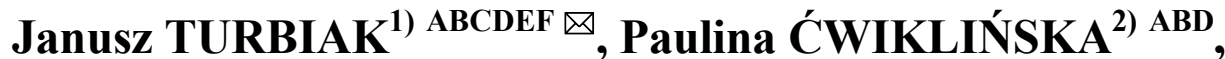 \\ Filip DUDA ${ }^{3)}$ BDEF
}

1) Institute of Technology and Life Sciences, Kuyavian-Pomeranian Research Centre, ul. Glinki 60, 85-174 Bydgoszcz; e-mail: j.turbiak@itp.edu.pl,jturbiak@poczta.onet.pl

2) University of Gdańsk, Faculty of Biology, Department of Plant Taxonomy and Nature Conservation, ul. Wita Stwosza 59, 80-308 Gdańsk; e-mail: paula.cwiklinska@gmail.com

3) University of Gdańsk, Faculty of Oceanography and Geography, Department of Hydrology, ul. Bażyńskiego 4, 80-952 Gdańsk; e-mail: filduda@gmail.com

For citation: Turbiak J., Ćwiklińska P., Duda F. 2017. Carbon dioxide emission from raised bog surface after peat extraction. Journal of Water and Land Development. No. 35 p. 237-242. DOI: 10.1515/jwld-2017-0089.

\begin{abstract}
Research on $\mathrm{CO}_{2}$ emission from a raised bog after completion of peat extraction was performed in 20112013. $\mathrm{CO}_{2}$ emissions were determined by the chamber method. Twenty years after the termination of peat extraction, the bog surface was almost entirely devoid of plants. $\mathrm{CO}_{2}$ emission from the bog varied depending on temperature and water conditions and was $418 \mathrm{mg} \cdot \mathrm{m}^{-2} \cdot \mathrm{h}^{-1}$ on average during the research period. $\mathrm{CO}_{2}$ losses on the raised bog were on average $19.7 \mathrm{Mg} \cdot \mathrm{ha}^{-1} \cdot$ year $^{-1}$ during the research period which corresponded to a carbon loss of $5.37 \mathrm{Mg} \cdot \mathrm{ha}^{-1} \cdot \mathrm{year}^{-1}$ or mineralisation of $9.6 \mathrm{Mg} \cdot \mathrm{ha}^{-1} \cdot \mathrm{year}^{-1}$ of organic mass of $56 \%$ carbon content. It is possible to reduce organic mass losses and $\mathrm{CO}_{2}$ emission to the atmosphere from the bog surface after peat extraction has been terminated by reconstruction of initial water conditions, i.e. retaining a high ground water level and restoration of aquatic plant communities.
\end{abstract}

Key words: $\mathrm{CO}_{2}$ emission, mineralization, raised bog, total ecosystem respiration

\section{INTRODUCTION}

Peat used to be extracted from raised bogs mainly to obtain energetic material. As more caloric fossil fuels appeared on the market, significance of peat decreased considerably. In recent years, peat deposits are extracted from raised bogs mainly to produce substrates for gardening purposes. The area of exploited raised bogs in the mid-1980s was estimated at 3763 ha [LIPKA 1984], whereas the area of raised bogs under extraction in 1996 was 1062 ha [ILNICKI 2002], which is about $0.5 \%$ of the total bog area in Poland.

One of the methods of raised bogs exploitation is milling. This method consists in lowering of the ground water level in a bog, cutting thin peat layers of several dozen mm, drying and collecting them [BIE-
NIEK, ŁACHACZ 2010]. This method results in a complete destruction of plan communities. It was observed that after exploitation of a peat deposit, despite restoration attempts, post-exploitation surfaces are not settled by plants and undergo gradual degradation, mainly due to mineralisation of organic mass resources [HERBICHOWA et al. 2009; ROCHEFORT 2003].

Spontaneous plant regeneration on raised bogs, degraded by peat exploitation, occurs to a very limited degree, due to unfavourable habitat conditions. Furthermore, as a result of peat milling, top layer of peat bog is completely removed over large areas. Along with the diasporas from which vegetation could reproduce. The main reason for a lack of regeneration is a persistent low ground water level due to drainage of peat deposits. The lack of protective effect of water 
and plants causes the surface of the peats to heat up, which hampers seed germination and seedling development [GIRARD et al. 2002; HERBICHOWA et al. 2009; SZAJDA, ŁABĘDZKI 2017]. An additional difficulty for plant development can also be extremely low $\mathrm{pH}$ of the substrate - even for acidophilous peat mosses occurring in raised bogs [MONEY 1994] and nutrient deficiencies.

As a result, even many years after the termination of peat exploitation, post-extraction sites remain almost entirely devoid of vegetation. Lack of vegetation results in a deterioration of $\mathrm{CO}_{2}$ balance and increased carbon losses. In Poland there has been no research into carbon losses on raised bogs after peat extraction termination. The aim of the paper is to determine $\mathrm{CO}_{2}$ emissions and carbon losses on a raised bog after termination of peat extraction.

\section{RESEARCH OBJECT AND METHODS}

The research was conducted on Czarne Bagno raised bog situated in the Łeba valley (Fig. 1) at a distance of about $10 \mathrm{~km}$ west from Lębork (Pomeranian province). Czarne Bagno is a Baltic raised bog. The original area of the bog dome was 226 ha, and peat thickness reached $8 \mathrm{~m}$, of which about $1.5 \mathrm{~m}$ was raised moss peat. At the end of the $19^{\text {th }}$ century Czarne Bagno was included in the system of ditches draining the whole Łeba ice marginal streamway. Particularly intensive drainage was carried out about 1970, which resulted in lowering of water table by 0.5 $\mathrm{m}$ in the whole area. Till the end of the 1950s the bog was covered by extensive peat extraction, and in 1987-1989 peat was extracted on an industrial scale by the milling method in an area of 9.2 ha. As a result, about one-metre-thick peat layer was harvested. In

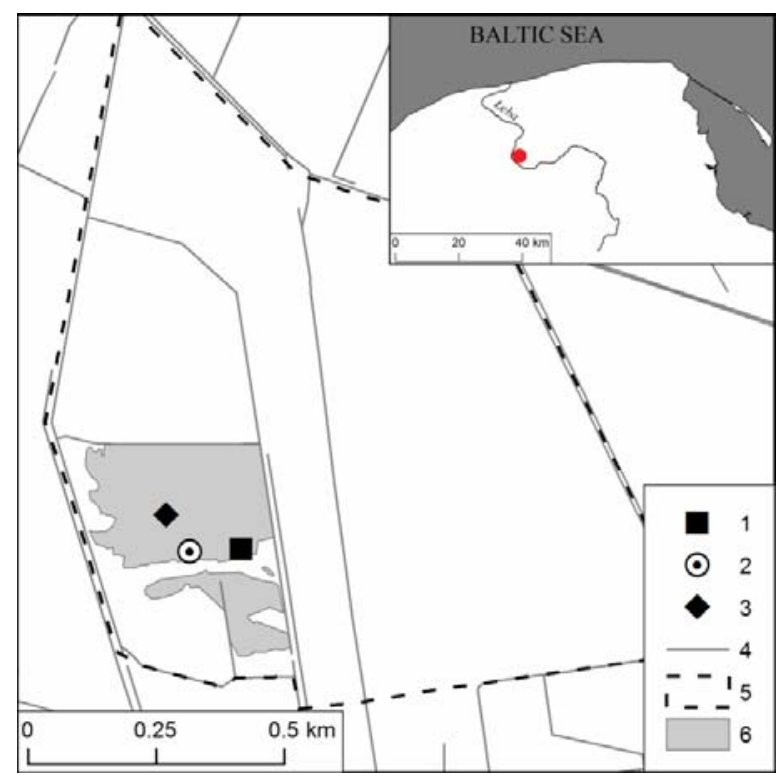

Fig. 1. Location of research area: $1=\mathrm{CO}_{2}$ emission measuring site, $2=$ piezometer, $3=$ meteorological station, $4=$ main ditches, $5=$ nature reserve boundary, $6=$ milling extraction areas; source: own elaboration
2006 a nature reserve was established on an area of 102.86 ha and renaturation steps were taken [DUDA et al. 2016; GDOŚ 2015, HERBICHOWA et al. 2007].

$\mathrm{CO}_{2}$ emission measurements were performed in 2011-2013, from April to October, at decade intervals by the chamber method, repeated twice. $\mathrm{CO}_{2}$ concentration changes in the chamber were determined using a photoacoustic meter (once a month) by taking a gas sample from the chamber to the meter in a closed circuit, and a diffusion meter (once-twice a month), which was placed inside the chamber. Dimensions of the chamber were $45 \times 45 \times 35 \mathrm{~cm}$. It was made of transparent acrylic glass and equipped with a ventilator, in order to maintain a uniform gas concentration inside, and a valve to equalise pressure between the chamber and the atmosphere. The chamber was sequentially placed in two square channel-bar frames permanently fixed to the analysed surface. The space between the frame and the chamber was sealed with water filling the frame. The bottom of the frame had blades which were driven into the ground surface to a depth of $5 \mathrm{~cm}$. During measurement the chamber was protected by a light-proof cover in order to reduce air temperature increase inside. Measurements were conducted between 10:30 am and 11:30 am. During measurement the air temperature inside the chamber was measured. $\mathrm{CO}_{2}$ emission measurement lasted about 6-8 minutes and the frequency of recording - every minute. In order to determine $\mathrm{CO}_{2}$ fluxes values the measurement of the first 2-3 minutes was used when $\mathrm{CO}_{2}$ concentration increase was linear. In 2011, 2012 and 2013 respectively, 16, 20 and 17 measurements of $\mathrm{CO}_{2}$ emissions were made, a total of $53 . \mathrm{CO}_{2}$ concentration changes in ppm were converted into $\mathrm{mg} \cdot \mathrm{m}^{-2} \cdot \mathrm{h}^{-1}$, according to the following formula [MOSIER, MACK 1980]:

$$
E=\rho \cdot V / A \cdot \Delta C / \Delta t \cdot 273 /(T+273)
$$

where: $E=$ flux value, $\mathrm{mg} \cdot \mathrm{m}^{-2} \cdot \mathrm{h}^{-1} ; \rho=$ gas density, $\mathrm{mg} \cdot \mathrm{m}^{-3} ; V=$ chamber capacity, $\mathrm{m}^{3} ; A=$ chamber area, $\mathrm{m}^{2} ; \Delta C / \Delta t=$ mean rate of gas concentration changes in time, $\mathrm{ppmv} \cdot \mathrm{h}^{-1} ; T=$ temperature inside chamber, ${ }^{\circ} \mathrm{C}$.

$\mathrm{CO}_{2}$ emission annual value was calculated using the regression equation describing the relationship between soil respiratory activity and air temperature according to LLOYD and TAYLOR [1994]:

$$
T E R=R_{\text {ref }} \cdot \exp \left\{E_{0} \cdot\left[\left(1 /\left(T_{\text {ref }}-T_{0}\right)\right]-\left[1 /\left(T-T_{0}\right)\right]\right\}\right.
$$

where: $T E R=$ total respiratory activity, $\mathrm{mg} \cdot \mathrm{m}^{-2} \cdot \mathrm{h}^{-1}$; $R_{\text {ref }}=$ respiration in reference temperature at $10^{\circ} \mathrm{C}$, $\mathrm{mg} \cdot \mathrm{m}^{-2} \cdot \mathrm{h}^{-1} ; E_{0}=$ activation energy coefficient; $T_{\text {ref }}=$ reference temperature $-283.15 \mathrm{~K} ; T_{0}=$ constant temperature in which biological processes are initiated $227.1 \mathrm{~K} ; T=$ soil or air temperature, $\mathrm{K}$.

Function parameters $R_{\text {ref }}$ and $E_{0}$ were matched to the data set using Statistica 7.1 programme. The obtained regression equation was used for modelling the 
Table 1. Mean monthly air temperature, ${ }^{\circ} \mathrm{C}$

\begin{tabular}{|c|c|c|c|c|c|c|c|c|c|c|c|c|c|}
\hline \multirow{2}{*}{ Year } & \multicolumn{12}{|c|}{ Temperature in month } & \multirow{2}{*}{ Mean } \\
\hline & $\mathrm{I}$ & II & III & IV & $\mathrm{V}$ & $\mathrm{VI}$ & VII & VIII & IX & $\mathrm{X}$ & $\mathrm{XI}$ & XII & \\
\hline 2011 & -0.2 & -3.9 & 3.1 & 10.1 & 13.0 & 17.8 & 18.2 & 17.6 & 14.0 & 8.8 & 5.1 & 3.2 & 8.9 \\
\hline 2012 & 0.1 & -4.1 & 3.8 & 7.2 & 12.4 & 14.4 & 17.6 & 16.9 & 13.6 & 7.8 & 5.3 & -1.4 & 7.8 \\
\hline 2013 & -1.5 & -0.2 & $\begin{array}{l}-1.7 \\
\end{array}$ & 6.2 & 13.6 & 15.7 & 17.5 & 16.7 & 11.5 & 9.7 & 5.4 & 2.8 & 8.0 \\
\hline Mean & -0.5 & -2.7 & 1.7 & 7.8 & 13.0 & 16.0 & 17.8 & 17.1 & 13.0 & 8.8 & 5.3 & 1.5 & 8.2 \\
\hline
\end{tabular}

Source: own elaboration.

Table 2. Mean ground water levels, $\mathrm{cm}$

\begin{tabular}{|c|c|c|c|c|c|c|c|c|c|c|c|c|c|}
\hline \multirow{2}{*}{ Year } & \multicolumn{12}{|c|}{ Ground water level in month } & \multirow{2}{*}{ Mean } \\
\hline & $\mathrm{I}$ & II & III & IV & $\mathrm{V}$ & VI & VII & VIII & IX & $\mathrm{X}$ & $\mathrm{XI}$ & XII & \\
\hline 2011 & -13.7 & -17.5 & -19.1 & -19.4 & -32.2 & -43.0 & -39.0 & -33.5 & -25.6 & -23.2 & -22.0 & -13.3 & -25.1 \\
\hline 2012 & -1.5 & 0.0 & 0.0 & -0.6 & -10.1 & -19.5 & -5.7 & $\begin{array}{ll}-1.1 \\
\end{array}$ & 0.0 & 0.0 & 0.0 & 0.0 & -3.2 \\
\hline 2013 & 0.0 & 0.0 & 0.0 & 0.0 & 0.0 & -11.5 & -21.8 & -23.8 & -20.7 & -17.8 & -11.6 & -6.6 & -9.5 \\
\hline Mean & -0.1 & -0.6 & -1.6 & -4.6 & -14.0 & -24.7 & -22.2 & -19.5 & -15.1 & -10.9 & -6.8 & 0.6 & -10.0 \\
\hline
\end{tabular}

Source: own elaboration.

course of respiratory activity in the following years, using air temperature measurements taken hourly. Air temperature measurements were performed on an automatic meteorological station situated within the research object (Tab. 1).

The data for ground water level in the bog area where milling extraction was performed was obtained from the hydrological monitoring network. Mean daily water levels (for measurement days) from a piezometer situated $100 \mathrm{~m}$ from the $\mathrm{CO}_{2}$ emission measurement site were used. The average water levels in 2011-2013 are presented in Table 2. The coordinates were obtained from the Digital Terrain Model [CODGiK 2011].

Ash content of soil samples was determined by ashing at a temperature of $550^{\circ} \mathrm{C}$, soil $\mathrm{pH}$ in $1 \mathrm{~N} \mathrm{KCl}$. Water properties of soil were determined by ZAWADZKI [1973] method by taking soil into cylinders of $100 \mathrm{~cm}^{3}$ capacity in four repetitions from subsequent 10 -cm-thick layers.

\section{RESULTS}

$\mathrm{CO}_{2}$ emission measurements were performed on the surface of a bog after industrial peat extraction was terminated. Even twenty years after the termination of peat extraction, the surface of the soil where $\mathrm{CO}_{2}$ emission was measured was almost entirely devoid of plants, mainly due to very low $\mathrm{pH}$ values (Tab. 3).

In 2011-2013 from April to October the mean $\mathrm{CO}_{2}$ emission value was $418 \mathrm{mg} \cdot \mathrm{m}^{-2} \cdot \mathrm{h}^{-1}$. The highest $\mathrm{CO}_{2}$ emission values were recorded in 2011 - on av- erage $469 \mathrm{mg} \cdot \mathrm{m}^{-2} \cdot \mathrm{h}^{-1}$, and the lowest in 2013 - on average $365 \mathrm{mg} \cdot \mathrm{m}^{-2} \cdot \mathrm{h}^{-1}$ (Tab. 4). The higher emission value in 2011 than in 2012-2013 was caused by persistently low ground water level of $25.1 \mathrm{~cm}$ below ground level. Favourable oxygen conditions stimulated the respiratory activity of soil microorganisms thus increasing $\mathrm{CO}_{2}$ emission.

In particular months of the research period the lowest value was recorded in April - on average 176 $\mathrm{mg} \cdot \mathrm{m}^{-2} \cdot \mathrm{h}^{-1}$. In May the mean $\mathrm{CO}_{2}$ emission value was almost three times higher than in April and was 497 $\mathrm{mg} \cdot \mathrm{m}^{-2} \cdot \mathrm{h}^{-1}$. The highest emission value was recorded in June $-690 \mathrm{mg} \cdot \mathrm{m}^{-2} \cdot \mathrm{h}^{-1}$. In subsequent months i.e. July, August and September the emission values diminished reaching $300 \mathrm{mg} \cdot \mathrm{m}^{-2} \cdot \mathrm{h}^{-1}$ in October (Tab. 4). The lowest $\mathrm{CO}_{2}$ emission values were observed in the months with the lowest air temperatures i.e. in April and October $\left(7.8\right.$ and $8.8^{\circ} \mathrm{C}-$ Table 1$)$.

No close correlation was however observed between air temperature and $\mathrm{CO}_{2}$ emission in summer months. Although the highest mean temperature was recorded in July $\left(17.8^{\circ} \mathrm{C}\right) . \mathrm{CO}_{2}$ emission in this month was $514 \mathrm{mg} \cdot \mathrm{m}^{-2} \cdot \mathrm{h}^{-1}$ and was by $25.5 \%$ lower than in June when mean temperature was $16.0^{\circ} \mathrm{C}$. This indicates that apart from temperature. $\mathrm{CO}_{2}$ emission value is considerably influenced by water conditions.

An analysis of the relationship between respiratory activity and ground water table level indicates a very strong diversity of $\mathrm{CO}_{2}$ emissions with the same ground water level (Fig. 2). Even in conditions of a complete saturation of the soil profile with water very high $\mathrm{CO}_{2}$ emission values were observed. When ground water level remained at the soil surface. $\mathrm{CO}_{2}$

Table 3. Soil physical and water properties

\begin{tabular}{|c|c|c|c|c|c|c|c|}
\hline \multirow{2}{*}{ Layer } & Ash content, \% DM & Bulk density, Mg·m & \multicolumn{4}{|c|}{$\mathrm{pH}$} & \multicolumn{3}{|c|}{ Water $\left.\mathrm{capacity}^{-3} \mathrm{~cm}^{3} \cdot \mathrm{cm}^{-3} \cdot 100\right)$ at $\mathrm{pF}$} \\
\cline { 5 - 8 } & $\bar{x} \pm S D$ & $\bar{x} \pm S D$ & $1 \mathrm{~N} \mathrm{KCl}$ & 0.0 & 2.0 & 2.7 & 4.2 \\
\hline $0-10$ & $7.51 \pm 0.37$ & $0.094 \pm 0.009$ & 2.52 & 98.4 & 79.4 & 45.9 & 11.1 \\
\hline $10-20$ & $6.11 \pm 0.25$ & $0.097 \pm 0.003$ & 2.28 & 98.4 & 78.0 & 43.3 & 11.9 \\
\hline $20-30$ & $2.67 \pm 0.15$ & $0.078 \pm 0.004$ & 2.30 & 98.6 & 79.5 & 35.6 & 12.5 \\
\hline $30-40$ & $3.92 \pm 0.16$ & $0.073 \pm 0.003$ & 2.36 & 98.6 & 76.3 & 32.0 & 8.7 \\
\hline
\end{tabular}

Explanations: $\bar{x}=$ mean value, $S D=$ standard deviation.

Source: own study. 
Table 4. $\mathrm{CO}_{2}$ emission from bog surface after peat extraction

\begin{tabular}{|c|c|c|c|c|}
\hline \multirow{2}{*}{ Month } & \multicolumn{2}{|c|}{$\mathrm{CO}_{2}$ emission a year, $\mathrm{mg} \cdot \mathrm{m}^{-2} \cdot \mathrm{h}^{-1}$} & \multirow{2}{*}{ Mean } \\
\cline { 2 - 4 } & 2011 & 2012 & 2013 & $x \pm S D$ \\
\hline IV & $222 \pm 110^{*}$ & $255 \pm 38$ & $51 \pm 35$ & $176 \pm 110$ \\
\hline V & $878 \pm 134$ & $338 \pm 209$ & $277 \pm 120$ & $497 \pm 331$ \\
\hline VI & $834 \pm 15$ & $699 \pm 38$ & $537 \pm 168$ & $690 \pm 149$ \\
\hline VII & $493 \pm 288$ & $665 \pm 63$ & $382 \pm 39$ & $514 \pm 142$ \\
\hline VIII & $324 \pm 85$ & $428 \pm 220$ & $513 \pm 170$ & $422 \pm 95$ \\
\hline IX & $272 \pm 162$ & $281 \pm 102$ & $431 \pm 291$ & $328 \pm 89$ \\
\hline X & $264 \pm 104$ & $271 \pm 147$ & $365 \pm 83$ & $300 \pm 57$ \\
\hline Mean & $469 \pm 276$ & $420 \pm 214$ & $365 \pm 192$ & $418 \pm 52$ \\
\hline
\end{tabular}

Explanations as in Tab. 3.

Source: own study.

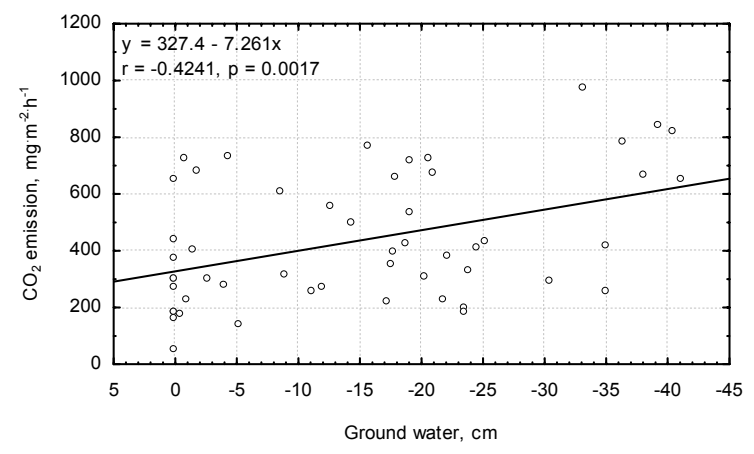

Fig. 2. Relationship between $\mathrm{CO}_{2}$ emission and ground water level; source: own study

emission was from $51 \mathrm{mg} \cdot \mathrm{m}^{-2} \cdot \mathrm{h}^{-1}$ on 08.04 .2013 to $722 \mathrm{mg} \cdot \mathrm{m}^{-2} \cdot \mathrm{h}^{-1}$ on 04.06 .2012 . The reason for the persistence of high soil respiratory activity in conditions of long lasting high ground water level was the ability of microorganisms to use oxygen from oxidised mineral compounds such as iron and manganese oxides as proton acceptor [GLIŃSKI et al. 1983; STĘPIEWSKA et al. 2004]. What follows is that even a short lowering of ground water level resulting in oxidation of mineral compounds makes the mineralisation process possible to proceed in condition of a complete filling of soil pores with water.

A high diversity of $\mathrm{CO}_{2}$ emission was also observed when ground water level remained at a depth of about $35 \mathrm{~cm}$ below ground level. In the first half of 2011 (from 12.05 to 14.07). $\mathrm{CO}_{2}$ emission was about $700 \mathrm{mg} \cdot \mathrm{m}^{-2} \cdot \mathrm{h}^{-1}$, whereas in the second half of this year - about $300 \mathrm{mg} \cdot \mathrm{m}^{-2} \cdot \mathrm{h}^{-1}$ (Fig. 3). Such a substantial decrease in $\mathrm{CO}_{2}$ emission was partially related to lower air temperature in that period and could also be related to a depletion of the supply of easily decomposed organic compounds by aerobic microorganisms or a termination of their intense development which resulted in diminished respiratory activity.

The most favourable conditions in terms of reducing $\mathrm{CO}_{2}$ emission from post-exploitation areas were those when ground water level remained high for a long time. In the period from the end of August 2012 to the end of May 2013, when ground water level remained close to soil surface, a clear reduction in $\mathrm{CO}_{2}$ emission value was observed. In that period only one record revealed emission above $400 \mathrm{mg} \cdot \mathrm{m}^{-2} \cdot \mathrm{h}^{-1}$, and on 26.05 .2013 it was only $161 \mathrm{mg} \cdot \mathrm{m}^{-2} \cdot \mathrm{h}^{-1}$. A lowering of ground water level in mid-June 2013 due to high air temperature did not however cause a rapid $\mathrm{CO}_{2}$ emission increase. Throughout July $\mathrm{CO}_{2}$ emission remained at a level of about $400 \mathrm{mg} \cdot \mathrm{m}^{-2} \cdot \mathrm{h}^{-1}$, and its gradual increase was recorded only in the second half of August (Fig. 3). As a result $\mathrm{CO}_{2}$ emission value was the smallest in 2013 at a level of $365 \mathrm{mg} \cdot \mathrm{m}^{-2} \cdot \mathrm{h}^{-1}$.

It was observed that the strongest reduction of the organic mass mineralisation rate in peat soils can be obtained only in conditions of long-lasting high ground water level. Changes in these conditions even a short-term lowering of ground water level resulted in an increase in $\mathrm{CO}_{2}$ emission values.

The mean values of $\mathrm{CO}_{2}$ emission from the postextraction surface ranged within the scope of $\mathrm{CO}_{2}$ emission variability determined for low bogs entirely devoid of plants and retained as bare fallow. On low bogs in the Noteć valley in four sites differing in water conditions the highest respiratory activity was observed in moist and dry complexes - 510 and 470 $\mathrm{mg} \cdot \mathrm{m}^{-2} \cdot \mathrm{h}^{-1} \mathrm{CO}_{2}$ respectively then in a periodically dry one $-420 \mathrm{mg} \cdot \mathrm{m}^{-2} \cdot \mathrm{h}^{-1}$ whereas the lowest in a wet complex $-330 \mathrm{mg} \cdot \mathrm{m}^{-2} \cdot \mathrm{h}^{-1}$ [TURBIAK et al. 2009].



Fig. 3. $\mathrm{CO}_{2}$ emission from bog surface and ground water level in 2011-2013; source: own study 
Higher values were obtained by AERTS and LUDWIG [1997] who determined $\mathrm{CO}_{2}$ emission from eutrophic and mesotrophic bogs at 13.1 and $15.2 \mathrm{~g} \cdot \mathrm{m}^{-2} \cdot \mathrm{d}^{-1} \mathrm{re}-$ spectively i.e. 546 and $633 \mathrm{mg} \cdot \mathrm{m}^{-2} \cdot \mathrm{h}^{-1}$. Similar $\mathrm{CO}_{2}$ emission figures from optimally water-logged peatmuck soils remaining in the condition of bare fallow were obtained by MALJANEN et al. [2004], who determined $\mathrm{CO}_{2}$ emission at a level of $158 \mathrm{mg}$ $\mathrm{C}-\mathrm{CO}_{2} \cdot \mathrm{m}^{-2} \cdot \mathrm{h}^{-1}\left(580 \mathrm{mg} \mathrm{CO} \cdot \mathrm{m}^{-2} \cdot \mathrm{h}^{-1}\right)$.

$\mathrm{CO}_{2}$ emission value in a year was calculated on the basis of the regression equation describing the relationship between $\mathrm{CO}_{2}$ emission and air temperature gauged during measurements (Fig. 4). Thanks to that daily and seasonal fluctuations in temperature were taken into account in calculations.

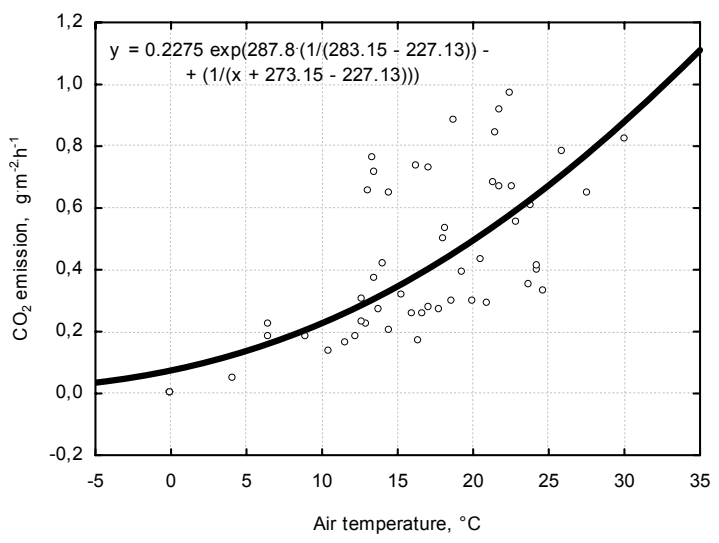

Fig. 4. Relationship between air temperature and $\mathrm{CO}_{2}$ emission; source: own study

In 2011-2013 on average $19.7 \mathrm{Mg} \mathrm{CO} \cdot \mathrm{ha}^{-1} \cdot \mathrm{year}^{-1}$ was emitted from the surface of the raised bog after peat extraction. This accounts for a carbon loss of $5.37 \mathrm{Mg} \cdot \mathrm{ha}^{-1} \cdot$ year $^{-1}$ or $9.6 \mathrm{Mg} \cdot \mathrm{ha}^{-1} \cdot$ year $^{-1}$ loss of organic mass of $56 \%$ carbon content (Tab. 5).

Table 5. $\mathrm{CO}_{2}$ emission value and losses of carbon (C) and of organic mass

\begin{tabular}{|c|c|c|c|c|}
\hline \multirow{2}{*}{ Parameter } & \multicolumn{3}{|c|}{ Losses, $\mathrm{Mg} \cdot \mathrm{ha}^{-1} \cdot \mathrm{year}^{-1}$} & \multirow{2}{*}{ Mean } \\
\cline { 2 - 4 } & 2011 & 2012 & 2013 & \\
\hline $\mathrm{CO}_{2}$ & 21.8 & 18.3 & 19.0 & 19.7 \\
\hline $\mathrm{C}$ & 5.94 & 4.99 & 5.18 & 5.37 \\
\hline Organic mass & 10.6 & 8.9 & 9.2 & 9.6 \\
\hline
\end{tabular}

Source: own study.

Lower carbon loses were found in closed peat mines in Estonia. In five mines the average $\mathrm{C}-\mathrm{CO}_{2}$ emission from the post-mining areas was 2,845 $\mathrm{Mg} \cdot \mathrm{ha}^{-1} \cdot$ year $^{-1}$ [SALM et al. 2012].

It could be assumed that due to very low $\mathrm{pH}$ and small nutrient content in raised bog respiratory activity and organic mass mineralisation rate would be substantially smaller than in low bog rich in nutrients. The obtained results reveal that on a drained raised bog there is a very intensive process of organic mass mineralisation and organic mass losses are similar as in eutrophic low bogs.
The calculated carbon losses on the raised bog were almost identical as the values given by the Intergovernmental Panel on Climate Change. According to IPCC in moderate climate carbon losses on drained nutrient-poor organic soils are $5.3 \mathrm{Mg} \cdot \mathrm{ha}^{-1} \cdot \mathrm{year}^{-1}$ whereas in nutrient-rich soils they are 6.1 $\mathrm{Mg} \cdot \mathrm{ha}^{-1} \cdot$ year $^{-1}$ [IPCC 2013].

\section{CONCLUSIONS}

1. Mean value of $\mathrm{CO}_{2}$ emission from the bog surface after extraction was $418 \mathrm{mg} \cdot \mathrm{m}^{-2} \cdot \mathrm{h}^{-1}$ for the research period. $\mathrm{CO}_{2}$ emission depended on temperature and water conditions. The highest emission values were observed in June while the lowest in April and October. i.e. in months with the lowest air temperatures.

2. On the raised bog after peat exploitation there is a very intensive process of organic mass mineralisation at a level similar to that in low eutrophic bogs. $\mathrm{CO}_{2}$ losses on the raised bog in the research period were $19.7 \mathrm{Mg} \cdot \mathrm{ha}^{-1} \cdot \mathrm{year}^{-1}$ on average which corresponded to a carbon loss of $5.37 \mathrm{Mg} \cdot \mathrm{ha}^{-1} \cdot \mathrm{year}^{-1}$ or mineralisation of $9.6 \mathrm{Mg} \cdot \mathrm{ha}^{-1} \cdot \mathrm{year}^{-1}$ of organic mass of $56 \%$ carbon content.

3 . It is possible to reduce organic mass losses and $\mathrm{CO}_{2}$ emission to the atmosphere from the bog surface after peat extraction by reconstruction of initial water conditions i.e. retaining a constant and high ground water level and restoration of plant communities.

\section{Acknowledgement}

Scientific work financed from funds for science in 20102013 as research project N305 3853339.

Meteorological and hydrological data were obtained within the project "Ecological restoration of habitats and vegetation on degraded raised bogs of Pomeranian province" subsidised from the funds of ERDF of Operational Programme Infrastructure and Environment 2007-2013. National Fund for Environmental Protection and Water Management in Warszawa and Provincial Fund for Environmental Protection and Water Management in Gdańsk.

\section{REFERENCES}

AERTS R., LuDWIG F. 1997. Water-table changes and nutritional status affect trace gas emissions from laboratory columns of peatland soils. Soil Biology Biochemistry. Vol. 29 (11/12) p. 1691-1698.

BIENIEK A., ŁACHACZ A. 2010. Rekultywacja gruntów pogórniczych kopalni torfu „Budwity” [Reclamation of postmining areas of the 'Budwity' peat excavation]. Zeszyty Naukowe Uniwersytetu Zielonogórskiego. $\mathrm{Nr}$ 137. Inżynieria Środowiska. T. 17 p. 138-150.

CODGiK 2011. Numeryczny model rzeźby terenu, arkusz: N-33-60-A-c-2-3, N-33-60-A-c-2-1 [Digital elevation model, sheets: N-33-60-A-c-2-3, N-33-60-A-c-2-1]. Warszawa. Centralny Ośrodek Dokumentacji Geodezyjnej i Kartograficznej.

DUDA F., JERECZEK-KORZENIEWSKA K., JOKIEL J., WOŹNIAK E. 2016. The influence of forms of peat extraction on present hydrological conditions of Baltic raised bogs. In: Geography in the face of modern world challenges. 
Ed. G. Chaberek-Karwacka, M. Malinowska. Kraków. Wydaw. LIBRON p. 149-163.

GDOŚ 2015. Łebskie Bagna PLH220040 - dokumentacja planu zadań ochronnych (PZO) [The Łeba Marshes PLH220040 - documentation of protection tasks project (PZO)] [online]. Warszawa. Generalna Dyrekcja Ochrony Środowiska. [Access 10.01.2017]. Available at: http://pzo.gdos. gov.pl/dokumenty/pzo/item/1719pzo-lebskie-bagna-plh 220040.html

Girard M., LAVOIE C., Theriault M. 2002. The regeneration of highly disturbed ecosystem: a mined peatland in southern Quebec. Ecosystems. Vol. 5 p. 274-288.

GliŃSKi J., StĘPNIEWSKI W., ŁabUdA S. 1983. Pobieranie tlenu i wydzielanie dwutlenku węgla w środowisku glebowym [Oxygen uptake and carbon dioxide emission in soil environment]. Problemy Agrofizyki. T. 39. ISSN 0137-6586 pp. 72.

Herbichowa M., ĆWiklińsKa P., SADOWSKa A. 2009. Restytucja roślinności torfowiskowej po przemysłowym wydobyciu torfu - założenia. dotychczasowe doświadczenia $\mathrm{i}$ wyniki [Restoration of bog flora in former peat excavation areas: assumptions, previous experience and results]. Przegląd Przyrodniczy. T. 20. Z. 3-4 p. 43-53.

Herbichowa M., PAWlaczyk P., StańKo R. 2007. Ochrona wysokich torfowisk bałtyckich na Pomorzu. Doświadczenia i rezultaty projektu LIFE04NAT/PL/000208 PLBALTBOGS [Conservation of the Baltic Raised Bogs in Pomerania, Poland. Experience and results of the LIFE04NAT/PL/000208 PLBALTBOGS Project]. Świebodzin. Wydaw. Klubu Przyrodników. ISBN ISBN 978-83-87846-96-1 pp. 149.

ILNICKI P. 2002. Torfowiska i torf [Peatlands and peat]. Poznań. Wydaw. AR. ISBN 83-7160-243-X pp. 606.

IPCC 2013. Supplement to the 2006 IPCC Guidelines for National Greenhouse Gas Inventories: Wetlands [online]. [Access 18.01.2017]. Available at: http://www. ipcc-nggip.iges.or.jp/public/wetlands/pdf/Wetlands separate_files/WS_Chp2_Drained_Inland_Organic_Soils.pdf

LIPKA K. 1984. Ocena gospodarcza złóż torfowych w Polsce. W: Gospodarka zasobami przyrody [Economic assessment of peat deposits in Poland. In: Nature resources management]. Ed. S. Kozłowski. PAN Komitet Przestrzennego Zagospodarowania Kraju. Studia. T. 85 p. 56-77.
LlOYD J., TAYlOR J.A. 1994. On the temperature dependence of soil respiration. Functional Ecology. Vol. 8. No. 3 p. 315-323.

Maljanen M., Komulainen V.M., Hytonen J., MartiKAINEN P.J., LAINE J. 2004. Carbon dioxide, nitrous oxide and methane dynamics in boreal organic agricultural soils with different soil characteristics. Soil Biology Biochemistry. Vol. 36(11) p. 1801-1808.

MONEY R.P. 1994. Restoration of lowland raised bogs damaged by peat extraction - with particular emphasis on sphagnum regeneration. Department of Animal and Plant Sciences. University of Sheffield pp. 229.

Mosier A.R., MACK L. 1980. Gas-chromatographic system for precise, rapid analysis of nitrous oxide. Soil Science Society of America Journal. Vol. 44 p. 1121-1123.

ROCHEFORT L. 2003. North American approach to restoration of Sphagnum dominated peatlands. Wetland Ecology and Management. Vol. 11 p. 3-20.

Salm J.-O., Maddison M. Tammik S., SoOsaar K., TruU J., MANDER Ü. 2012. Emissions of $\mathrm{CO}_{2}, \mathrm{CH}_{4}$ and $\mathrm{N}_{2} \mathrm{O}$ from undisturbed, drained and mined peatlands in Estonia. Hydrobiologia. Vol. 692. Iss. 1 p. 41-55.

StęPNiewsKa Z., PrZywara G., BenNicelli R.P. 2004. Reakcja roślin w warunkach anaerobiozy [Plant response in anaerobic condition]. Acta Agrophisica. Rozprawy i Monografie. Nr 7. Lublin. Instytut Agrofizyki PAN. ISSN $1234-4125$ pp. 86.

SZAJDA J., ŁABĘDZKI L. 2017. Wyznaczanie optymalnego poziomu wody gruntowej na zmeliorowanych użytkach zielonych w zależności od ewapotranspiracji rzeczywistej i rodzaju gleby [Determining optimum groundwater table depth on meliorated grasslands depending on actual evapotranspiration and soil type]. Woda-ŚrodowiskoObszary Wiejskie. T. 17. Z. 1(57) p. 115-134.

Turbiak J., MiatKowski Z., Bolewski T. 2014. Wpływ warunków wodnych na aktywność respiracyjną gleb pobagiennych bez pokrywy roślinnej [Effect of water condidtions on respiration activity of post-bog soils under the conditions of plant cover lack]. Woda-Środowisko-Obszary Wiejskie. T. 14. Z. 4(48) p. 123-134.

ZAWADZKI S. 1973. Laboratoryjne oznaczanie zdolności retencyjnych utworów glebowych [Determination of field water capacity of the soil profile on the basis of $\mathrm{pF}$ curves]. Wiadomości IMUZ. T. 11. Z. 2 p. 11-31.

\section{Janusz TURBIAK, Paulina ĆWIKLIŃSKA, Filip DUDA}

\section{Emisja ditlenku węgla z powierzchni torfowiska wysokiego po zakończonej eksploatacji torfu}

\section{STRESZCZENIE}

Badania emisji $\mathrm{CO}_{2} \mathrm{z}$ torfowiska wysokiego po zakończonej eksploatacji torfu prowadzono w latach 20112013. Emisję $\mathrm{CO}_{2}$ oznaczano metodą komorową. Powierzchnia torfowiska po dwudziestu latach od zakończenia eksploatacji torfu była prawie całkowicie pozbawiona roślin. Emisja $\mathrm{CO}_{2} \mathrm{z}$ torfowiska była zależna od temperatury $\mathrm{i}$ warunków wodnych. Wynosiła ona średnio w okresie badań $418 \mathrm{mg} \cdot \mathrm{m}^{-2} \cdot \mathrm{h}^{-1}$. Straty $\mathrm{CO}_{2}$ na torfowisku wysokim wynosiły średnio w okresie badań $19,7 \mathrm{Mg} \cdot \mathrm{ha}^{-1} \cdot \mathrm{rok}^{-1}$, co związane było z ubytkiem $5,37 \mathrm{Mg} \cdot \mathrm{ha}^{-1} \cdot \mathrm{rok}^{-1}$ węgla lub mineralizacją $9,6 \mathrm{Mg} \cdot \mathrm{ha}^{-1} \cdot \mathrm{rok}^{-1}$ masy organicznej o zawartości $56 \%$ węgla. Ograniczenie strat masy organicznej i emisji $\mathrm{CO}_{2}$ do atmosfery z powierzchni torfowiska po zakończonej eksploatacji torfu jest możliwe po odtworzeniu pierwotnych warunków wodnych, polegających na utrzymywaniu wysokiego poziomu wody gruntowej oraz restytucji zbiorowisk roślinnych.

Słowa kluczowe: całkowita respiracja ekosystemu, emisja $\mathrm{CO}_{2}$, mineralizacja, torfowisko wysokie 